\title{
Representation of Hell in Daqa'iq al-akhbar by Ibn Ahmad al-Qodi and La Divina Commedia by Dante Alighieri (Perspective of Mythology)
}

\author{
$1^{\text {st }}$ Pradibyo Herdiansyah $^{1}, 2^{\text {nd }}$ Iik Arifin Mansurnoor $^{1}, 3^{\text {rd }}$ Yusuf Rahman $^{2}$ \\ \{pradibyo_herdiansyah19mhs.uinjkt.ac.id ${ }^{1}$, iik.arifin@uinjkt.ac.id ${ }^{1}$, yusuf.rahman@uinjkt.ac.id\} \\ UIN Syarif Hidayatullah, Islamic Studies Department, Jakarta, Indonesia ${ }^{1}$ \\ UIN Syarif Hidayatullah, Ushuluddin Department, Jakarta, Indonesia ${ }^{2}$
}

\begin{abstract}
This research seems to indicate; 1), the concept of hell and its classification, 2) then compare the mythology of religious values in the book Daqa'iq al-Akhbar and La Divina Commedia. As a doctrine that exists in every religion, hell has a discussion that is often debated because each religion has a narrative characteristic to explain its definition and truth. Both East and West, they have written and literary works that reveal the truth of hell. Furthermore, this paper will analyze the comparison between the two understandings with the Roland Barthes mythological approach through critical qualitative descriptive research. The result of this study seems to indicate that there are significant similarities in understanding the concept of hell in Daqa'iq al-Akhbar and La Divina Commedia, although there are several different depictions of the physical form of hell.
\end{abstract}

Keywords: Dante, Hell, Islam, Mythology.

\section{Introduction}

Religion as a doctrine will never be separated from the call for sin and reward. So to save his followers needed a piece of good news (bashiran) and threats (nadhiran). Good news has the implication of being a reward while the threat of being tortured. Torture is given to those who do good, instead, torture is inflicted on sinners as a reward. Then torture and reward are interpreted in two forms, namely, torture and reward when living (instant karma) and life after death [1].

Whether life after death does exist or is just a myth will remain a mystery to human life itself. But at least there is a lot of literature to uncover the truth about the existence of "Resurrection Day". Both hell as a picture of torture and heaven as a reward, both of them remain unseen things, can only be believed but cannot be seen in their realm of existence.

Even many Muslim scholars began in the Middle Ages with a variety of theological schools discussing matters related to the afterlife. Mu'tazila, for example, gives the opinion that hell is prepared for sinners during their lifetime and vice versa, heaven is prepared for those who do good. Then they add a place between heaven and hell called "manzila bayna manzilatayn" which is the worst place for sinners, they are forever adrift in the afterlife [2].

Even in ancient traditions such as in Java, some literary works such as songs also explain the concept of hell both its geographical image or even its classification according to its 
inhabitants, as described in Serat Centhini and Pathak Serat. Both of them explain the nature of hell for the purification of the human spirit to go to heaven [3]. Whereas in another written source in Hinduism, Atharvaveda, it is stated that Nerakaloka is a very black place, very different from Suwargaloka. Many female ghosts and witches become the inhabitants of hell, besides the sinful Atman (spirit) while living in arcapadha (world) [4].

Returning to the concepts that exist in Islam, hell is explained in many verses of the Qur'an and the hadith of the prophet in various names, such as al-nar, al-sa'ir, al-hutoma, jahannam, lada, saqar, jahim, and al-hawiya, which certainly has a special meaning in the naming faithful [5]. Only by the hints in the two sources of law can a Muslim imagine the hell in their minds, whether it is true or not, a belief and faith in revelation is an obligation. As the prophet Mohammed witnessed while traveling on Isra 'and Mi'raj, he was shown the forms of hell and the status of the inhabitants as well as the guardian angels and other creatures in the abyss of hell [6].

Some Muslim scholars also gave their opinions about drawing hell for a time when the progress of theological science was developing. One of them is Ibn Qayyim al-Jauziya (d. 751/1350), he argues in his book Shifa 'al-'Alil that hell is not limited to torture for sinners but is also a hospital or prison as a place where cruelty is used in the name of goodness with certain limits, because with sanctification is a grace of God will be obtained. Likewise, Ibn 'Araby (d. 638/1240), argues in his book al-Futuhat al-Makkiya that the torment of hell is not an eternal torment even for hell experts themselves there is no eternal torment for them [7]. And there are many more depictions of hell in the books of interpretation, philosophy, and aqeedah from Muslim scholars. Among these again there is the book 'Azama Allah wa Makhluqotihi which was attributed to al-Shaykh Ja'far ibn Hayyan al-Asbahani (d. 369 h). This book is not far from the two books above, explaining some unseen things in the concept of Islamic religion starting from the majesty of God, His creation in heaven and the world, creatures that reside between the two and live between the life of the world and heaven. And of course, this book also discusses the characteristics of hell. In the explanation of k. al'Azamah, the author is not fixated on the description of the Prophet Muhammad about the hell that is obtained from Isra 'mi'raj, but also quotes from several other prophets' stories. This book is almost similar to the Buluqiya story in the way it is delivered [8].

The book which is the main topic in this paper is Daqa'iq al-akhbar fi dhikr al-janna wal-nar, which is one of the books that is not much different from us al-'Azamah, which explains the creation of a noble spirit - commonly referred to as the Holy Spirit in Christianity namely Nur Muhammad as the beginning of all creation. Then proceed with the creation of Adam, angels, demons, devils, jinn, humans, death, the realm of barzakh, hell, heaven, and other topics related to the supernatural [9]. The author's commentary on this book is still under debate. Some argue that this book is an essay from Abu 1-Layth al-Samarqandi (d. 983), Fakhr al-Din al-Razi (d. 1210), and 'Abd al-Rahim al-Qadi (fl. Before 11th / 17th c.) with a different title, namely the Qurrat al-'uyun. There are also those who attribute this book to Imam alSuyuti (d. 1505) with the title al-Durar al-hisan fi al-ba'thi wa na'im al-jinan [10]. Basically, the designation and the author's reference refer to one book that is the main object in this paper, namely the 1984 Beirut publication - written as al-Qadi's writing and on the side of the page written al-Durar al-hisan by al-Suyuti.

In this book Ibn Ahmad al-Qodi presents explanations in detail in each chapter. The sources and references of this book refer to many of the Companions of the Prophet Muhammad, such as Ibn 'Abbas (d. 687), and other scholars such as Abu al-Layth (d. 983).

Like other classical Arabic books, Daqa'iq al-Akhbar is widely studied in various Islamic boarding schools, especially on the island of Java. However, some researchers doubt the 
source of the argument from this book because there is no mention of a verse or hadith that is clear sanad and matan in exposure to the concept of heaven and hell, even some people assume there is an element of isra'liyyat in this book. Even so, the Daqa'iq book still has authority in understanding the secret concept of the creation of the universe as a material for thought that follows the understanding of ahlu al-sunnah wa al-jama'ah - Abu al-Hasan alAsh'ari (d. 935) and Muhammad al-Maturidi (d. 944) - as in other books such as Ihya 'by alGhozali (d. 1111).

What is more interesting about this book is the detailed presentation of sub-themes which are rarely found in other books that share with him. For example, when describing the creation of creatures, this book explained that everything in the world comes from the nur Muhammad (the light of the Prophet Muhammad). Then nur Muhammad lived for 70,000 years in a tree called muttaqien while continuously praising his Lord. When God placed a mirror of His creation before Nur Muhammad he was ashamed to see his form from that mirror, then he was dripping with sweat. And from that sweat created the spirits of the prophets, the companions of the Prophet, and all other entities. And it is also told that the obligation to pray 5 times comes also from 5 times the lightness of Nur Muhammad's eyes [11].

It would be even more interesting if the concept of hell in this book - which incidentally is a religious book written by an ulama - is compared with a literary work. With a different scientific background between writers and scholars, it will certainly be a contradictory analysis, but there is a harmony between the two. Because not only in scientific work the concept of hell is explained. Some Arabic writers gave the concept of hell in their poetry or prose, as requested in the book of al-Aghani, Adam b. 'Abd al-'Aziz who was humming with his poetry to the caliph al-Mahdi (ruling 775-85). He called "zabaniyah" namely the grim reaper who would help the angel Malik in hell [12]:

"Isqini ya Mu'awiyah ... sab'atan aw thamaniyah
Isqiniha wa-ghannini ... qabla akhdhi l-zabaniyah"

"Give me to drink, oh Mu'awiya ... seven or eight [cups]!

Give them to me to drink, and sing for me ... before the zabaniya take [me]!"

The above poem fragment shows that one of the concepts of hell is the material for the expression of literary works. It can also be assumed that the author can interpret zabaniyah in his poem because he has obtained a break from the religious doctrine conveyed by several scholars. Then the author gives a modification with a touch of literary value so that new interpretations appear as he wishes, even giving rise to a controversial concept.

From the assumptions above the writer is motivated to research a phenomenal Italian literary work, The Divine Comedy (with the original title discussing Italian La Divina Commedia) by Firenze literary writer, Dante Alighieri (d. 1321). This work is written in three chapters, the first being Inferno (Hell) - this first part will be the subject of this research, Purgatorio (Purgatory), and Paradiso (Paradise). Dante wrote this work from 1308-20 a year before his death [13]. From a first-person perspective, he related his journey to the three stages above through his guide Virgil - the ancient Roman poet, author of Aeneid. He gave a picture of hell more than what the Gospel wrote and mixed Christian theology and Greco-Roman pagan myths so that the characters and the gods could be reinterpreted in a way that made sense. For example Charon, one of the Greek mythological beings whose task is to take the soul to the underworld, in the Divine Comedy he was assigned to transport the damned to hell. Some of the histories of the world were not separated from the portrayal of Dante, like Judas 
the traitor of Christ, he was punished by being bitten by one of Satan's three mouths. And in the other mouth are Brutus and Cassius traitor Julius Caesar [14].

Even more surprising, Dante witnessed in his journey the figures of the Prophet Muhammad and Ali who were being tortured in "Malebolge", the eighth level of hell, he said with his poetry Canto XXVIII lines 28-33 [15]:

"Mentre che tutto in lui veder m'attacco,
guardommi e con le man s'aperse il petto,
dicendo: <<Or vedi com' io mi dilacco!"
“vedi come storpiato è Mäometto!
Dinanzi a me sen va piangendo Ali,
fesso nel volto dal mento al ciuffetto."

Longfellow's translation:

"While I was all absorbed in seeing him,

He looked at me, and opened with his hands

His bosom, saying: 'See now how I rend me;"

"How mutilated, see, is Mahomet;

In front of me doth Ali weeping go,

Cleft in the face from forelock unto chin;"

Dante called the prophet Muhammad in Italian with the term "Maometto", according to him the sin that caused the prophet Muhammad and Ali, to go to hell was the division of religious people - especially Christians, because Dante himself was a Christian, he was baptized in his hometown - which was caused by the second mission [16].

Based on the two points of view of the two works above, several problems were found, including how exactly the classification of hell in the concept k. Daqa'iq and La Divina, why one religious figure can be categorized as a dweller of hell in another religious concept, and how the two concepts are complementary and mutually critical. So to understand the two texts about a religious message that must be believed to be true but not yet proven, a relevant perspective is needed to give meaning and meaning to the text's utterance.

In Daqa'iq and La Divina also have a significant and special signify to convey a sign. For example, in this discussion, the marker is a concept of language (punishment), and then the sign is a mental picture of punishment, and the sign is the relationship between the concept and mental image that gives birth to one meaning, namely: purification of the soul. So the authors chose the Roland Barthes approach to myth to analyze topics about the hell that exists in the paper above because myths according to Barthes are not only shaped in speech or oral but can also be through writing [17]. Then through the theory of the second order semiotic system, there will be obtained some significance of religious myths that exist in Daqa'iq and La Divina.

From the description above, this research will reveal the classification of each hell in the Daqa'iq al-Akhbar and La Divina Commedia through the perspective of Roland Barthes mythology, so that the conclusions of this study will result in an understanding of some of the hellish concepts of Islam represented by Daqa'iq book and some hellish concepts from Christianity delivered by La Divina Comedia. It will also be concluded that each of the 
concepts of hell from both of them has a religious mythic value which is the doctrine of the religion.

This Word document can be used as a template for journal. This Word document can be used as a template for journal. This Word document can be used as a template for journal. This Word document can be used as a template for journal. This Word document can be used as a template for journal

\section{Methods}

This research is descriptive qualitative research by explaining the classification of hell and its concepts in the book Daqa'iql al-Akbar and La Divina Commedia with the perspective of Roland Barthes's mythological semiology. This descriptive research will be explained through narrative data obtained from primary and secondary sources.

K. Daqa'iq al-akhbar by 'Abd al-Rahim Ibnu Ahmad al-Qadi and La Divina Commedia Chapter Inferno written by Dante Alighieri is the primary data source, the Daqa'iq book used is the edition published by Dar Ihya' al-Kutub al- 'Arabiyah Indonesia and Beirut published. The La Divina translation in English used in this study is the translation of Henry Wadsworth Longfellow and can be accessed from digitaldante. columbia.edu. And secondary sources in this study are several books, journals, reports, etc. that are not directly related to the main object. This secondary source is also a means of assisting researchers in solving problem formulations.

To collect data researchers used two methods, namely critical analysis with the method of reading and recording. As for the analysis of these data, the researchers used four methods as follows [18]; 1) collecting data according to the purpose of the study, in this case the data about the concept of hell in the two books that have been mentioned then the data is validated through triangulation methods and peer discussion; 2) reduce the data that has been obtained and classify it carefully according to the concept of hell that is in both books; 3) data exposure and analysis; 4) researchers produce conclusions on the answers to research problems.

To lead to the desired conclusion, as mentioned, the researcher uses the mythological approach in representing the meaning of hell in both research subjects. And it has also been mentioned before that language - in this discussion means in its current understanding is the text - according to Barthes is a system of signs that reflects the assumptions of a particular society in a certain time [19], from these assumptions then came connotations (secondary signs) which were inserted an ideology called a myth. The connotation itself has subjective meaning or at least intersubjective. In other words, denotation as the primary sign is what is depicted as an object, while the meaning of connotation is how to describe it [20]. So in the meaning of the connotation, the meaning of an object will be different between one reader and another reader, and this is what Barthes refers to as the birth of the reader and death of the author. This is reinforced by Barthes's opinion that the text is not composed of rows of words that release a "theological meaning" (meaning the message from God-Author) but is a multidimensional space in which several writings have been mixed and disputed, nothing is original from them, so the text is a weave of quotations from thousands of cultural sources. Then the functioning of a connotation requires the activeness of the reader [19]. So in the meaning of the connotation, the meaning of an object will Then Barthes explains how the sign works to produce a connotative sign (pragmatic sign) from the denotative marker (syntagmatic sign) as mentioned by Cobley \& Jansz as a map of sign funcioning [21]: 
Table 1. Barthes's sign functioning.

\begin{tabular}{|c|c|c|}
\hline 1. signifier & 2. signified & \\
\hline \multicolumn{2}{|c|}{3 denotative sign } & \\
\hline \multicolumn{2}{|c|}{ 4. CONNOTATIVE SIGNIFIER } & 5. CONNOTATIVE SIGNIFIED \\
\hline \multicolumn{3}{|c|}{6 CONNOTATIVE SIGN } \\
\hline
\end{tabular}

From the map above it can be seen that the denotative sign (3) consists of signifier (1) and signified (2). However, at the same time, denotative double is also a connotative marker (4). In other words, it is a material element: only if the sign "lion" - for example, can connotations such as self-esteem, courage, and ferocity become possible.

In relation to the narrative text, according to John Lechte [22], Barthes reviewed that there are 5 codes in the text, namely: 1) the hermeneutic code, which is a puzzle code that revolves around the reader's expectations to get the "truth" for questions that arise in the text; 2) the semic code, the many connotative codes that offer many facets; 3 ) the symbolic code, the most typical structural fiction coding; 4) the proairetic code (the logic of actions); 5) the gnomic code, which is a text reference to objects that are known and codified by culture. This coding was intended by Barthes to explicate the narrative codes that apply in a realist text in the Sarrasine novel written by French literary Honore de Balzac. Using these 2 steps, the writer will identify the connotative meaning of the hellish markers in the Daqa'iq and La Divina poems.

\section{Finding and Discussion}

By using the method of analysis of the research object, namely k. Daqa'iq and La Divina and using the mythological approach, the researchers obtained several findings based on the data obtained, as follows:

\subsection{First Hell: al-Nar}

This book describes hell and its contents with an explanation that is not much different from the descriptions in the Qur'an and hadith, only spiced up with several descriptions that are not found in both. Even in this book as explained earlier it also explains related supernatural myths of nature such as doomsday, blowing of trumpets, forms of spirits, images of demons, depictions of angels of life, to Buraq mythological creatures who were mounted by prophet Muhammad when Isra 'Mi'raj.

It will be a little different from La Divina - which is a fiction literary work, this book explains the depiction of the concept of hell with the conditions for the doctrine that comes from several Qur'anic verses as well as hadiths and news from friends. The concept of hell in this book is made into nine chapters, as follows;

The First: the thirty-fourth chapter fi dhikri l-nar (explanation of hell), this chapter describes the general state of hell. The beginning of making hell when God burned it for 1,000 years until it was red, then burned again 1,000 years until it was white and finally burned in 
the same time period so that it was pitch black like a pitch black night without the slightest light (iswaddat ka l-layl li l-zulmi la yutfa' u lahibuha). Al-Qadi quotes in his explanation of hell from Imam al-Mujahid (d. 722) and Ibn 'Abbas (d.687), that in hell there are many snakes the size of camels and scorpions the size of donkeys ready to devour the experts of hell. And as for the awesomeness of the fires of hell - told through the dialogues of the Angel Gabriel and the guardian angels of hell - is when a date palm is dropped on the earth surely the sky will never drip its water and there will be no plants that can live there. And the lightest torture in hell is when hell experts wear hell's footwear, then with those sandals their brains boil and sound like a furnace that is boiling to the point of being choked by the entire population of hell [9]. It is also told from the hadith that hell on earth is the seventieth type of fire from hellfire. From there formed a myth that it is recommended for a Muslim to perform ablution after eating food that is heated with fire. There is even a myth that causes extreme weather on earth, both hot and cold, is due to a gust of fire [23].

The Second: he thirty-fifth chapter (fi dhikri abwab l-nar), describes the 7 gates of hell, the names, and their respective inhabitants. Furthermore, it is stated in this book that every door of hell is divided between men and women. Each of the 7 doors is 700 years away on earth and the heat of each door is 70 times that of the door afterward.

The most basic first door is called Hawiyah (deep abyss), its inhabitants are hypocrites, people who deny the Lord's Supper (man kafara min ashab i-ma'idah), and followers of the Pharaoh. The second is called Jahim (a blazing fire), the inhabitants are polytheists. The third is Saqar (fire) and is inhabited by al-sabi'in, ie pagan people (paganism). The four inhabited by Satan and his worshipers (satanism) and majus (Zoroastrians), this hell named Laza (a burning fire). The fifth is the Hutamah Hell (destroying), inhabited by Jews (Zionism). The six are named Sa'ir (lake of fire), and the inhabitants are Christians.

The seventh hell is not mentioned implicitly related to its name. But it is explained in this book that when the Prophet Muhammad asked the Angel Gabriel about the seventh hell he only answered its inhabitants, they were the people of the prophet Muhammad who committed great s6ins and did not have the chance to repent before his death.

The classification is closer to the division of hell based on the types of religious people who came before Islam or the Muslims themselves, starting from the hypocrites and those who do not believe in the miracles of the Prophet Jesus and then the pagans, angels, gods, etc. then other religions outside Islam.

There are many myths in this description of the classification of hell, including myths about people who betrayed Jesus. Mentioned in this kitab by the name of man kafara min ashab l-ma'dah, this sentence explains explicitly about people who do not want to believe or even deny the food banquet brought by Prophet Isa from the sky as a sign of his miracles. Perhaps this also explains the first classification of hell is not a Christian, and also explained that before that Christians in the Daqa'iq eschatology are found in the sixth layer hell. The story about ashab l-ma'idah is also explained in the Qur'an surah al-Ma'idah verse 112. AlTabari (d. 923) explained in his interpretation through the narration from Qatadah (d. $117 \mathrm{H})$ that food (ma'idah) came down from heaven complete with heavenly fruits, then the people of Jesus were instructed not to hide the food but there was some who betrayed the order then Allah punished them by cursing them to be apes and pigs [24].

Furthermore, the people who denied the Prophet Isa were in Hawiyah along with the hypocrites, it could be assumed that al-Qadi placed them in the same layer because their sins were almost the same. The traitors of the Prophet Jesus sinned for ignoring the commands of their prophet even though they knew that Jesus was a divine messenger, while hypocrites 
ignored religious commands even though they knew something that was forbidden but they still did.

Another myth is illustrated in the third layer of hell classification, namely al-sabi' in people. Some commentaries explain that al-sabi'in are people who used to follow al-Masih then they made their religion by worshiping angels, stars, and gods that they made into statues [25]. From there the authors classify al-sabi'in as adherents of paganism because of the similarity of their belief concepts.

Then there are also devil worshipers and Zoroastrians or magi. For Satanists there has been much mention in the Qur'an, like surah al-Baqarah: 27 that Satan is the leader of unbelievers, then Surah Yasin: 60 which forbids the worship of Satan, because Satan is a real enemy. In this Daqa'iq it is also explained by the narration of the story of the prophet Zakariya how Satan stole someone's faith - al-bab al-thamin fi dhikr al-shaytan kayfa yaslubu al-iman - so he left the path of truth. The myth that appears in some Islamic doctrines is that the kahin (shamans) get a whisper from the devil to find out the news of the sky and then they use it to predict something magical. Even to assist them in practicing the magic they use to enchant or appease others with the help of Satan [26].

Then there are also religious followers of majus in this layer as well, although their presence long before Islam is still mentioned in al-Qur'an, one of them in Surah al-Hajj: 17. They are Zoroastrians, worshiping Lord Ahura Mazda [27]. Zoroastrians were adherents of the ancient Persian religion that existed from 1,500 BC to $1,000 \mathrm{BC}$, they considered fire and air to be twin substances in purity and essential for purification so that worship in a fire was shot. In the western literary world, their book Arda Viraf has changed its way to Hell and Heaven long before Dante's La Divina was composed. Or, even in its current development, where they prefer contemporary popular culture in the West, let's say one of them is Freddie Mercury - the legendary singer of the Queen - inspired by the beliefs of Persian origin [28]. But basically, it can be assumed that they are categorized as hell dwellers in the Daqa'iq because they do not believe in the prophethood of Muhammad and do not worship Allah.

Adherents of Judaism and Christianity occupy the fifth and sixth levels of hell. It is no stranger to the teachings of Islam that intersect with these two religions, many verses of the Qur'an and the hadith of the prophet about these two religions. They are also considered to be a community of Ahl-Kitab, which is permissible for a Muslim to marry a woman of that religion may also eat animals slaughtered by them [29]. This is different when leaning against other religions. The one interpretation of the Qur'an that states the sins of Jews and Christians so that it is categorized as a great sinner is the interpretation of the first letter in its last verse, which is Surah al-Fatihah. Ibn Kathir (d. $774 \mathrm{H})$ explains that the word al-maghdub 'alayhim (who earn Thine anger) is Jewish and the word al-dallun (who go astray) is a Christian [30]. Jews are referred to like people who are the wrath of God, perhaps because they know the truth of the teachings of God, but they do not want to do so they debate a lot with the prophets in each era so that many get a curse and adhab. Not much different from Christians, they are lost because they believe in the crucifixion of the true Prophet Jesus - in the Islamic view appointed by God before the crucifixion itself.

The Third: thirty-sixth chapter (fi dhikr Jahannam). al-Qadi does not explain the reason for adding a separate chapter about one of these names of hell. Or perhaps the name Jahannam is the seventh name of hell that is not named in the previous chapter, or it could also be that Jahannam is the general name of all hell classifications. As for the alquranalhadi.com index, Jahannam is mentioned no less than 67 times. Lange in his Introduction mentions more than 100 , all of which describe Jahannam as the worst place, retribution for sinners, a very painful punishment and other descriptions that connote to evil. 
In the Chronicles of Taymur it is even explained that Jahannam was on a journey through heaven, this is evidenced by the meeting of the Prophet Muhammad and the Angel Malik this incident occurred when Mi'raj - while in the third level of heaven, the prophet asked Malik to open the door of Jahannam, but refused, then a formless voice came and ordered Malik to open the Jahannam gate, then the gate was opened. After the gate was opened the prophet saw 90,000 cities made of iron, castles of brass, tin houses, and so on. This shows that Jahannam is not far from heaven [31].

What's interesting in $\mathrm{k}$. Daqa'iq, that Jahannam is described not only as something categorized as a place but Jahannam is a creature that has legs and mouths as creatures in Greek and Roman myths. As for the legs of hell, there are four (arba'u qawa'im), each of which is 1,000 years' walk on earth. The number of heads is 30 , in each head, there are 30,000 mouths and in each mouth there are 30,000 molars, 1,000 times the size of Mount Uhud - one of the war sites of the Prophet Muhammad in Arabia. Jahannam was imported on the Day of Judgment by being pulled by the teeth of 70,000 rows of angels whose numbers were more than humans and jinns. The mouth of hell has two big lips like the world. On that lip are 2 iron chains that have 70,000 links and are drawn by countless angels. Then Jahannam was brought in from the left side of 'Arsy on the Day of Judgment.

The Fourth: the thirty-seventh chapter ( $f$ i dhikr suqi l-nas ila l-nar) that is the chapter that explains the leading of humans to hell. This chapter explains the situation of sinners being led to hell. Perhaps this chapter refers to the Qur'anic verses al-Zumar ayar 71 and 72:

"And those who disbelieve are driven unto hell in troops till, when they reach it and the gates thereof are opened, and the warders thereof say unto them: Came there not unto you messengers of your own, reciting unto you the revelations of your Lord and warning you of the meeting of this your Day? they say: Yea, verily. But the word of doom of disbelievers is fulfilled." (Q. 39:71)

"It is said (unto them): Enter ye the gates of hell to dwell therein. Thus hapless is the journey's end of the scorners." (Q. 39:72)

The first discussion is about the word zumara (troops), in this context it is illustrated that sinners are led to hell by being bound together with the devil in pairs. And that is what is meant by the group of sinners, they are grouped with the devil.

The second is the existence of the angel Zabaniya as guardians of hell (khazanatuha: the warders thereof). When the sinners reached the gates of hell, Zabaniya raised a rhetorical question to them, "did your Lord not send messengers to warn you of the end of the day?" the al-'adhab had been appointed over them. Then the verses of the Surah Saba 'verse 42: "Taste the doom of the Fire which ye used to deny."

The state of the group is described by al-Qadi in a slightly vulgar diction with very pathetic circumstances. Zabaniya angels put chains from their mouths and penetrate to their anus, then their left hands are shackled to their necks and their right hands will be inserted into their chests until they pierce their backs. The angels will drag their faces and will continue to beat him using a giant hammer. In line with the description above, shackles (aghlal) and chains (salasil) have become one of the tools most often described in the concept of hell Daqa'iq.

As for Muslims who are herded into hell because of sin experience different conditions with other people, they are dragged by holding their beards, and some are dragged with their crested or gray hairs. 
The Fifth: the thirty-eighth chapter (fi dhikri al-Zabaniya), describes the guardian angels of hell. Like the previous chapter, Zabaniya has appeared as an angel welcoming sinners in hell. It's just in k. Daqa'iq there is another name that is also a guardian of hell, namely Malik. Al-Qadi explained that Malikat Malik was the leader of the Malikat Zabaniyah.

As for the shape, the guardian angels of hell have eyes like lightning, their lips touch the soles of their feet while licking the fire that burns from inside their mouths, the angels' teeth are white like ox horns. While the distance between the right and the left shoulder is equivalent to a year of foot travel on earth. They are also God's messengers to punish sinners so that they are not given the slightest compassion or mercy. Even when the Prophet Muhammad met and then greeted Malik he did not smile at all until he was instructed directly by God to smile at the prophet [6]. This description also has similar description in the book of al-Durr alfakhir by al-Ghazali [12].

The Sixth: the thirty-ninth chapter (fi dhikr ahli l-nar wa ta'amihim wa sharabihim). Describes food and drinks served to experts in hell. In his presentation, al-Qadi did not directly explain the type of food or drink experts of hell, he showed the sign (significant) through the story in the Prophet's hadith. Like when severe hell experts ask for rain from God for 1,000 years, but what comes out are snakes the size of camels (hayyat ka amthal a'naqi l$i b i l)$ and are ready to frown on them.

Then at the end of the new chapter implicitly explained the drink of the inhabitants of hell, namely boiling water (hamim). The hot water is a sign that the torment for the inhabitants of hell is very painful, because when they drink hamim their eyes and faces begin to fall out and when it reaches the stomach intestines and their hearts melt.

In addition there is zaqqum wood, which is a plant that grows in hell as one of its inhabitants' food. The description of zaqqum is mentioned in the Qur'an surah al-Saffat verses 62-66:

"Is Paradise a better accommodation or the tree of zaqqum?"

"Indeed, We have made it a torment for the wrongdoers."

"Indeed, it is a tree issuing from the bottom of the Hellfire,"

"Its emerging fruit as if it was heads of the devils."

"And indeed, they will eat from it and fill with it their bellies."

Al-Qadi explained the status of the inhabitants of hell when eating this plant with a hadith that was propped up against the prophet, that is when the inhabitants of hell ate their entrails to a boil. Then fire will come out of their mouths which burn their bodies so that all the limbs fall out under the soles of the feet. Perhaps this explanation can be used as an interpretation of the Qur'anic verses about zaqqum and hamim mentioned in a verse context, namely sura alDukhan verses 43-46:

"Indeed, the tree of zaqqum

Is food for the sinful.

Like murky oil, it boils within bellies

Like the boiling of scalding water (gholyi l-hamim)."

The essence of the explanation is that the sign in the form of zaqqum and hamim has a relationship with the sign that is a food and drink in hell that leads to a very terrible heat as a meal of the inhabitants of hell. And both these signs and omens signal to the pain of the torture experienced by the sinners in hell, and this also confirms that hell is the worst place. 
The Sevent: the fortieth chapter (fi dhikri anwa'i l-'adhab 'ala qodr a'malihim). This chapter describes the various types of torture received by residents of hell in accordance with his previous actions. The description of the torments is described through dialogue between the prophet Moses and Allah - as some of the descriptions in the Daqa'iq, many use this style. The first torture described by al-Qadi is a person who likes to break promises and break the mandate. They occupy hell Wayl, crucified in the zaqqum tree (masluban 'ala shajarah alzaqqum), will be put fire from the mouth to penetrate their rectum and out of their mouths, ears, and eyes. Not only that, but they will also be handcuffed along with the devil in a chain that is hung to the tongue and their brains will flow through both nostrils.

From the above concept of torture, then there is no clear explanation of the form of torture, especially those received by other sinners. As for sins other than the two above, such as those who commit adultery, leave prayers, eaters of usury, traders who cheat, and other sins. Their torment was only generalized and equated with the torment of the first two sins and it was only said that they would be tortured in hell for centuries. This was conveyed by alQadi to be an interpretation of the Qur'anic verse Labithina fiha ahqaba, "They will abide therein for ages". Furthermore, al-Qadi detailed the meaning of the word "ahqaba" with the hadith of the prophet who said that a century in the hereafter is 4,000 years in the world.

And interestingly, mentioned in this chapter is a mythical creature named Huraysh, a creature born from a scorpion. Its head is in the seventh layer of heaven and its tail is in the deepest layer of the earth. His job is to look for 5 groups of liars, those who do not want to pay zakat, those who are disobedient to parents, alcoholics, and people who talk about worldly matters in a mosque. After finding the five groups, Huraish swallowed them all and spewed them out in hell.

The Eighth: the forty-first chapter (fi dhikri sharibi l-khamr), explains the state of people who drink alcohol while in hell. There is no clear reason why the drinkers of khamr were made a separate chapter by al-Qadi and were not included in the previous chapter which more generally discusses the torture of sinners. Perhaps many of the drunks of Al-Qadi wrote this book so that they made a marker through the presentation of the torment of drunks in hell as a reminder not to continue the sin.

And not much different from other sinners, the drinkers of khamr are also punished by shackles, chains, boiling water, eating zaqqum trees and so on. Then another torture was added including putting it in a chest made of fire. After 1,000 years they were expelled and put in prison where snakes and scorpions took turns biting their legs.

And a few sentences from the end of this chapter explain that the drinkers of khamr who are Muslims are not eternal in hell because of the prophet Muhammad's piety. As if the statement also confirms this chapter as a reminder to those who like to drink khamr in the time of alQadi.

The Ninth: forty-second chapter ( $f$ d dhikri l-khuruj min al-nar). This chapter is the last chapter about the concept of hell, which explains about people who will be expelled from hell and put into heaven. For Muslims who go to hell they will finally be freed from all torture. Not much different from the liberation of drinkers khamr, Muslims can get out of torture because they get intercession from the prophet Muhammad. When Muslims come out of hell, they are burned and scorched by hellfire. Then the prophet Muhammad took them to a river in front of heaven called nahr al-hayah (river of life).

After they came out of the river, they changed to become younger, handsome, beautiful and shapely, so that their faces were like moonlight. It's just that on their foreheads they still have the inscription "they are people freed from Allah from hell" (ha'ulai 'utaqa l-Rahman 
min al-nar). Because former inhabitants of hell are ashamed of the inhabitants of heaven that existed before them, then they prayed that the writings be erased, God granted that request.

Thus some of the concepts and classifications of hell that exist in the Daqa'iq al-akhbar. It should be noted that there are several myths in the form of a creature that is not found in the world or forms of torture that no one has ever imagined in this world. As a doctrine, some descriptions of the concept of hell have been said to be enough to be a sign that has a relationship with the mark itself which is realized through the values of fear for readers of this book. In other words, the discussion about hell in its discussion from a normative point of view still has a message with various kinds of concepts as the second level of meaning in the delivery of those messages. Slightly different from the poetry of La Divina as a literary expression of feelings from Dante which overflowed his entire life experience - bearing in mind the masterpiece's work was completed 1 year before his death, this collection of lines of poetry had no intention of becoming a doctrine for the reader. Even though there are still some similar hellish concepts between Daqa'iq and La Divina and are interpreted in the following discussion.

\subsection{Second Hell: al-Nar and Inferno}

"MIDWAY upon the journey of our life

I found myself within a forest dark,

For the straightforward pathway had been lost."

(Inf. 1.1-3)

It was the first line of La Divina, Dante began his journey when he suddenly found himself in a dark forest. As we mentioned in the introduction, analyzing a literary work will be harder to find a concept in it, in contrast to Daqa'iq which is a non-literary work. Moreover, La Divina represents Dante's journey in Inferno through hundreds of lines of poetry which are divided into 34 Canto. Then the writer will only take a few lines of poetry in Inferno that have a relationship or difference with the concepts that exist in Daqa'iq.

The journey to hell is one of La Divina's main ingredients. Dante placed himself like the prophet Muhammad when carrying out Isra 'and mi'raj. If Gabriel is the prophet's guide then Virgil is Dante's guide on his tour in hell. Furthermore, Miguel Assin Palacios (d. 1944) - a Spanish scientist who wrote the book Islam and The Divine Comedy and published in 1926 said that Dante wrote his poem after he got the idea from reading an Arabic translation of Isra 'and mi' raj titled Mairaj The name by Bonaventura da Siena (d. 1274). Assin added that Dante also took some Islamic philosophy in La Divina from the writings of Ibn al-Araby and alMa'arri. La Divina is one form of Dante's rejection and anger over the development of Islam which was very influential in the Middle Ages in the Western world. So he put the prophet of the Muslims in his hell [32].

Even so, La Divina still has its authenticity which is certainly different from the concept of hell in Islam. And it must be admitted that Dante's work can present in detail every concept of his balance so that many painting artists make illustrations of Inferno, just call Sandro Botticelli's (d. 1490), Chart of Hell [33]. One form of Inferno's strengths in terms of detailed interpretation compared to Daqa'iq is the mention of the names of the sinners in several layers of hell. In

Daqa'iq it is very rarely found to mention someone's name, in contrast to La Divina where there is always someone's name at every level of balance. 
Slightly different from the level of hell in Daqa'iq, Inferno has 9 levels of hell, at the seventh level there are 3 more levels and the eighth level has 10 gaps. While the tenth level is divided into 4 parts. Like Daqa'iq, each level of Inferno is inhabited by certain sinners and certain penalties.

"THROUGH me the way is to the city dolent;"

(Inf. 3.1)

All hope abandon, ye who enter in !"

(Inf. 3.9)

The two lines of poetry above indicate to us that hell is a place with no hope for anyone who enters into it. This concept is also ad in Daqa'iq, if Dante uses the word city then in alQadi use the terms dar (house) and qarya (village) which also does not hope for sinners to repent in the afterlife, there is only a reward for deeds when alive.

"I knew, who in that Limbo were suspended."

(Inf. 4.45)

The first hell circle was named Limbo, a place of punishment for followers of Paganism and people who were not baptized but who did not sin. Their punishment is to be hunted by insects that are ready to always sting them. Slightly different from Daqa'iq in the first circle which is a place for people who do not believe in God's messenger in his time. The similarity of concepts for the first level is the same, namely placing in hell people who do not believe in the religion of each author.

Interestingly, Dante also mentioned that Salahuddin or in the west was more famous for Saladin, a Muslim war general from the Saracens, as well as Ibn Sina and Ibn Rushd in Limbo. That can be proven by the line of poetry below:

"and Euclid the geometer, and Ptolemy,"

"Hippocrates and Galen, Avicenna,"

"Averroes, of the great Commentary."

(Inf. 4.142-4)

Ibn Sina and Ibn Rushd were with Greek philosophers namely Ptolemy, Hippocrates, and Galen. Perhaps Dante put them in the same circle because they were modern virtuous Pagans. Likewise, Saladin was also stationed at Limbo together with Brutus who overthrew Roman King Tarquinius (Inf. 4.127-9). Perhaps Dante put the two together because they had succeeded in overthrowing an empire [34].

Before Dante entered the second hell, he saw the figure of Minos, the guardian of hell. In Islam this creature is called Zabaniyah or Malik, this is also mentioned in Daqa'iq. [15]. The second hell circle is occupied by the Lustful, where Raty Cleopatra was there, along with Achilles, Paris, and Tristan. Dante categorizes them as humans who are dominated by lust. Their punishment is blown forever by storm winds, Dabte said in his poetry:

"by that assailing wind, lament and moan; so that I asked him: 'Master, who are those who suffer punishment in this dark air?', (Inf. 5.49-51) 
The second level in Daqa'iq is a place for the polytheists, while people who are controlled by lust only mention the torment that is shackled and chained that pierced their bodies.Third Circle is a place for the Gluttons, greedy people are punished with discomfort, lying in filth and muck like pussy and sense assaulted. Underneath them a beast shaped like a dog that has three heads named Cerberus (Inf. 6.13-15). In Daqa'iq it is also explained about the punishment which is mixed similar to being made as a pig, but the situation is experienced by the sinner when he is resurrected in the desert. The fourth circle is occupied by the Greedy and the Spendthrifts. Dante gives a picture with the figure of Plutus (Inf. 7.2), the God Greek of Wealth, and also Fortuna (Inf. 7.62). Of course, the names of such gods cannot be found in Daqa'iq, but only mention of the punishment for the rich but do not zeal his property.

Fifth circle, Dante sees the Angry and the Sullen, they are thrash about frustration and fight each other; the sullen sulk under water sighing, blowing bubbles, and refusing all action. In his balance at Canto 7-9, Dante also saw another Greek mythological creature, Medusa, a human-headed snake, and snake-shaped snake. Dante also saw Hercules, a demigod from Greece. The sixth hell is a place for the Heresy, their torment is trapped in the burning embers. Dante sees Epicurus and his followers (270 B.C.E.). He argues that pleasure without pain and passion is the highest kind of human beings. The seventh hell is a place for those who commit murder, suicide, slander, sodomy, usurious eaters (Inf. 7.12-17). Dante saw their punishment by drowning in blood, trapped in a tree whose spears pierced them and left naked in the burning sand. The concept of punishment with a tree is almost the same as the concept in Daqa'iq which is the zaqqum tree. There are also many mythological creatures seen by Dante here, such as the Minotaur (half-buffalo human) and Centaur (half-horse human).

Furthermore, in the eighth hell, Dante is the sinner of plimping and seducing, flattery, simony, sorcery, political corruption, hypocrisy, theft, fraudulent rhetoric, divisiveness, and falsification (Inf. 24-30). Punishment for them also varies, namely Whipped by demons, flipped upside down in holes and their feed set on fire. The thief is described by Dante with the figure of Vanni Fucci, a thief of a sacred object in one of the cathedrals in Florence, punished by being condemned to be a snake (Inf. 24.5). And as the author has mentioned in the introduction, Dante described divisiveness with the figures of the prophets Muhammad and Ali, both punished by being mutilated (Inf. 28).

And the ninth hell is divided into four parts, namely Caina (Inf. 32.59), for murderers of family-members, Antenora (Inf. 32.88) for traitors to political party or country, Ptolomea (named after Maccabean general who slew ambassadors) for same sinners, Guidecca for traitors to lodgers and benefactors, Center of Earth for Satan, Judas, Brutus, and Cassius. In this hell, Dante also saw Lucifer with 3 mouths who were biting the two traitors of Julius Caesar namely Brutus and Cassius and then in the other mouth there was Judas, traitor of Christ.

This concept is almost similar to the understanding of Jahannam in Daqa'iq which describes it as a creature that has a mouth and also bites sinners. Then one concept that Dante wrote under the title Purgatory (purgatory) is almost the same as nahr al-hayah (river of life) in Daqa'iq. Both of them are mediators connecting heaven and hell, and both are sanctification for sinners in hell who have finished serving their punishment and are going to heaven. A little different is the medium, Purgatory. 


\section{Conclusions}

From the discussion that the author has explained, it can be seen that the classification of hell in k. Daqa'iq al-akhbar has 7 levels, different from the one in La Divina Commedia which has 9 circles of hell. The main concept in Daqa'iq is that hell is a place for those who sin. It was explained that many of the inhabitants of hell were those who were polytheists, adherents of Paganism, Jews, Christians, hypocrites, and al-sabi'in. The myths in Daqa'iq are in the form of creatures in the form of angels, such as Zabaniya and Malik, the forms of Hellfire and Huraysh. For Muslims who have finished their sentence in hell, they can go to heaven, but before going through purification nahr al-hayah. La Divina is different from Daqa'iq in many concepts, including having 9 levels of hell, and in each hell described in detail the sins and punishment at each level. Where Daqa'iq only gives a general picture of the inhabitants of hell and their torments. There are many Greek mythological creatures mentioned at La Divina, such as Centaur, Minotaur, and Minos. In La Divina, the gatekeepers of hell are represented through the Minos figure, but in Daqa'iq they are represented by the angels of Zabaniyah and Malik. Hell in La Divina and Daqa'iq each tend to intersect religious values. Because La Divina is a literary work that emphasizes the imagination of the author while Daqa'iq is a nonliterary work that emphasizes the delivery of information in the hadith of the prophet or verses of the Qur'an. On the other hand, Daqa'iq classifies Dante as a Christian in the sixth level of hell, while Inferno classifies the prophet Muhammad as the leader of Islam in his eighth balance.

Acknowledgements. This research supported by The Graduate School of Islamic Studies UIN Syarif Hidayatullah.

\section{References}

[1] T. Tesei, „The Barzakh and The Intermediate State of The Dead in the Quran,“ rev. Locating Hell in Islamic Traditions, C. Lange, Ed., Brill., 2016, p. 31.

[2] H. Nasution, Teologi Islam: Aliran-Aliran Sejarah Analisa Perbandingan, Jakarta: UI-Press, 2011.

[3] C. Brakel-Papenhuyzen, „The Tale of Skull; An islamic description of hell in Javanese, “ KITLV, zv. $158, \% 1$. vyd.1, p. 5, 2002.

[4] I. A. G. A. Saraswati, „Konsep Suraga, Neraka, dan Moksa dalam Kakawin Candra Bairawa,“ Dharmasmrti, zv. XV, \%1. vyd.28, p. 38, 2016.

[5] A. Qarqaz, "The Role of the Qur'an in Developing the Linguistic Function of Single Words -"Hell" as a Model," Majalla Jami'a al-Najah li al-Abhath, vol. 31, no. 1, p. 3, 2017.

[6] N. a.-d. al-Ghoyti, Qisso al-Mi'raj, Semarang: Pustika al-'Alawiyyah.

[7] S. Pagani, „Ibn 'Arabī, Ibn Qayyim al-Jawziyya, and the Political Functions of Punishment in the Islamic Hell," rev. Locating Hell in Islamic Traditions, C. Lange, Ed., Brill, 2016, pp. 186-187.

[8] W. Raven, "Hell in Popular Muslim Imagination The Anonymous Kitāb al- Azama," in Locating Hell in Islamic Traditions , C. Lange, Ed., Brill, 2016, p. 145.

[9] '. a.-R. I. A. al-Qodi, Daqa'iq al-Akhbar, Indonesia: Dar Ihya' al-Kutub al-'Arabiya.

[10] C. Lange, „Introducing Hell in Islamic Studies,“ rev. Locating Hell in Islamic Traditions, C. Lange, 
Ed., Boston, Brill, 2016, p. 6.

[11] Safriadi, „Otoritas Kitab Kuning Dalam Putusan hakim: Analisis Putusan Hakim di Mahkamah Syar'iyah Lhokseumawe Aceh,“ Analisis: Jurnal Studi Keislaman, zv. 19, \%1. vyd.1, pp. 85-86, 2019.

[12] C. Lange, „Revisiting Hell's Angels in the Quran,“ rev. Locating Hell in Islamic Traditions, C. Lange, Ed., Boston, Brill, 2016, p. 74.

[13] D. Alighieri, al-Kumidiya al-Ilahiyya, Beirut: Mu'assasat al-'Alamiyya lil 1-dirasat wal 1-Nashr, 2002, p. 20.

[14] C. Blauvelt, "Dante dan Komedi Ilahi: Dia memandu kita dalam tur ke neraka," 2018. [Online]. Available: https://www.bbc.com/indonesia/vert-cul-44724677. [Accessed 89 2019]

[15] J. B. McCambridge, "Dante and Islam: a Study of the Eastern Influences in the Divine Comedy," 2016.

[16] T. Barolini, "Inferno 28: Tuscany’s Evil Seed Commento Baroliniano," 2018. [Online]. Available: https://digitaldante.columbia.edu/dante/divine-comedy/inferno/inferno-28/. [Accessed 99 2019].

[17] D. Swandayani, "Tokoh Cutural Studies Prancis: Rolan BArthes," Yogjakarta, 2005.

[18] M. Huberman, Qualitative Data Analysis, second ed., London: Sage Publications, 1994 .

[19] A. Sobur, Semiotika Komunikasi, 5th ed., Bandung: PT Remaja Rosdakarya, 2013.

[20] I. S. Wahyu, Semiotika Aplikasi Praktis bagi Penelitian dan Penulisan Skripsi Mahasiswa Ilmu Komunikasi, Jakarta: Universitas Prof. Dr. Moestopo (Beragama), 2006.

[21] P. Cobley and L. Jansz, Introducing Semiotics, UK: Icon Books, 1999, p. 51.

[22] J. Lechte, Fifty Key Contemporary Thinkers From Structuralism To Post-Humanism, 2nd ed., Canada: Routledge, 2008 , pp. 153-154.

[23] C. Melchert, „Locating Hell in Early Renunciant Literature,“ rev. Locating Hell in Islamic Traditions, C. Lange, Ed., Boston, Brill, 2016, p. 106.

[24] A. J. M. I. J. al-Tabari, Tafsir al-Tabari Jami'l al-bayan 'an ta'wil ayee al-Qur'an, 9 ed., Dar Hijr : Markaz al-Buhuth wa al-Dirasat al-'Arabiya wa al-Islamiya, 2001

[25] A. Jamarudin, „Kaum Shabi'in dalam Al-Qur'an,“ Jurnal Ushuluddin, zv. XIX, \%1. vyd.1, p. 72, 2013.

[26] T. Fahad, "al-Kahanah al-'arabiya qabla l-islam," Shirka Qodmus li al-Nashr wa al-Tawzi', Beirut.

[27] B. Zulyeno, "Sastra Persia; Perjalanan Panjang Menuju Nusantara dari Siyasat Name sampai Tajussalatin," Media Syariah, vol. XV, no. 1, p. 118, 2013.

[28] J. Bekhrad, „Zoroastrianisme: Agama asing yang mempengaruhi Barat,“ 254 2017. [Online]. Available: https://www.bbc.com/indonesia/vert-cul-39685556. [Cit. 159 2019].

[29] A. E. Putra, „Konsep Ahlul al-Kitab dalam Al-Qur'an Menurut Penafsiran Muhammed Arkoun dan Nurcholis Madjid,“ Al-Dzikra, zv. X, \%1. vyd.1, p. 48, 2016.

[30] A. a.-F. I. I. '. I. Kathir, Tafsir al-Qur'an al-'Azim, 1st ed., Riyad: Dar Tayyibah, 1999.

[31] F. Colby, "Fire in the Upper Heavens; Locating Hell in Middle Period Narratives of Muhammad's Ascension," in Locating Hell in Islamic Tradition, C. Lange, Ed., Boston, Brill, 2016, p. 132.

[32] B. Dar, "Influence of Islam on Dante's Divine Comedy," International Journal of English and Literature (IJEL), vol. 3, no. 2, p. 165, 2013.

[33] L. D. G. Cheney, "Illustration for Dante's Inferno: A Comparative Study of Sandro Btticelli, Giovanni Stradano, and Federico Zuccaro," Cultural and Religious Studies, vol. 4, no. 8, p. 487, 2016.

[34] J. M. Ziolkowski, "Intrduction; Dante and Islam," Dante Society of Ameruca, 2007. 